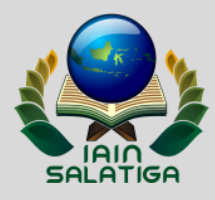

Jurnal Pamomong

ISSN: 2774-583x (Cetak) ISSN: - (online)

Website Jurnal: http://pamomong.iainsalatiga.ac.id

\title{
LAYANAN BIMBINGAN KONSELING ISLAM DENGAN TERAPI PUASA SENIN KAMIS DALAM MENINGKATKAN KESADARAN SHOLAT LIMA WAKTU REMAJA
}

\author{
Nanda Pramusinta ${ }^{1}$ \\ ${ }^{1}$ IAIN Salatiga
}

\begin{tabular}{l}
\hline \hline Informasi Artikel \\
\hline Histori Artikel: \\
Diterima 18 Juni 2021 \\
Revisi 24 Juni 2021 \\
Disetujui 28 Juni 2021 \\
\\
\hline Penulis Korespondensi: \\
Nanda Pramusinta \\
Email: \\
nandapramusinta3 @ gmail.com
\end{tabular}

\begin{abstract}
ABSTRAK
Layanan Bimbingan Konseling Islam adalah suatu usaha dalam memberikan bantuan terhadap dirinya yang mengalami kesulitan rohaniah baik mental dan spiritual. Tujuan dalam penelitian ini adalah untuk mengetahui pelaksanaan Bimbingan Konseling Islam dengan Terapi Puasa dalam Meningkatkan Kesadaran Sholat Lima Waktu Remaja. Metode penelitian yang digunakan adalah penelitian kualitatif dengan analisis deskriptif, dengan membandingkan perspektif teori yang meliputi 5 langkah yaitu : identifikasi masalah, diagnosis, prognosis, treatment/ terapi, evaluasi dan follow up. Dalam proses konseling konselor memberikan 3 tahap treatmen/terapi yaitu terapi puasa sebagai pemantauan diri, pemberian tugas dengan mengisi angket perilaku shalat harian, dan pemahaman shalat lima waktu dengan cara menjelaskan tentang tujuan shalat agar mendapat kesadaran tentang kewajiban melaksanakan shalat lima waktu. Hasil penelitian menunjukan bahwa dalam proses Bimbingan Konseling Islam dengan terapi puasa adanya perubahan kesadaran shalat lima waktu konseli. konseli melaksanakan shalat 5 waktu dan konseli menuruti saat ibunya meminta bantuan atau menyuruhnya.
\end{abstract}

Kata kunci: BK islam; puasa; shalat; remaja.

\section{PENDAHULUAN}

Manusia sebagai mahkluk Allah yang paling sempurna dianugrahi kemuliaan dan kelebihan dengan berbagai potensi yang dibawa sejak lahir. Salah satu yaitu fitrah kecenderungan beragama yang ditandai manusia menerima Allah sebagai Tuhan, sehingga pengakuan terhadap Allah sudah melekat kuat di dalam jiwa manusia. Dengan demikian individu yang baru lahir sudah mempunyai potensi untuk menjadi manusia yang percaya terhadap keberadaan Allah SWT dan menjalankan ajaran beragama yang baik (Padli, 2018). 
Kehidupan manusia (Life Span Development) bermula dari usia kandungan, infancy, bayi, remaja, dewasa, dan lansia sampai meninggal. Dalam setiap rentang kehidupan manusia mempunyai tugas perkembangan masing-masing yang harus dilalui oleh setiap manusia yang lahir di dunia. Setiap tugas perkembangan harus berkembang sesuai dengan masa, usia manusia dan tidak boleh ada yang terlewati jika itu terjadi akan sulit dirubah dan dididik kembali (Jannah, dkk., 2017). Perkembangan manusia yang sulit dibentuk yaitu ketika melalui fase remaja.

Masa remaja merupakan masa pemeliharaan antara kehidupan anak-anak dan kehidupa orang dewasa yang ditandai dengan pertumbuhan dan perkembangan biologis dan psikologis. Secara biologis ditandai dengan tumbuh dan berkembangnya seks primer dan sekunder sedangkan secara psikologis ditandai dengan sikap, perasaan, keinginan, dan emosi yang tidak menentu. Pada fase remaja dibagi menjadi empat yaitu fase pra-pubertas dengan usia 12-13 tahun, fase pubertas dengan usia 14-16 tahun, fase akhir pubertas dengan usia 17-18 tahun, dan fase remaja adolesen dengan usia 19-21 tahun. Masa remaja ditandai dengan sejumlah karakteristik yang meliputi pencapaian hubungan dengan teman sebaya, dapat menerima dan belajar peran sosial sebagai seorang pria atau wanita dewasa yang dijunjung tinggi oleh masyarakat, menerima keadaan fisik dan mampu menggunakannya secara efektif, mencapai kemandirian emosional dari orang tua dan orang dewasa lainnya, memilih dan mempersiapkan karir dimasa depan sesuai dengan minat dan kemampuan masing-masing remaja, mampu mengembangkan sikap positif terhadap pernikahan dikehidupan berkeluarga dan memiliki anak (Hidayati \& Farid, 2016).

Remaja sering digambarkan sebagai usia dimana manusia dapat ditolerir untuk melakukan banyak pelanggaran terhadap norma yang ada dalam masyarakat, pada akhirnya remaja bebas mencoba hal-hal yang melanggar aturan walaupun terlihat negatif. Dengan adanya kebebasan pers, media massa dengan bebasnya menanyakan sesuatu yang dapat memberikan dampak negatif bagi perilaku remaja saat ini. Media seperti televisi, internet merupakan media yang dapat memberi pengaruh besar terhadap perilaku (Padli, 2018).

Remaja merupakan individu yang sedang dalam proses berkembang kearah kematangan dan kemadirian. Untuk mencapai suatu kematang remaja harus mendapatkan suatu bimbingan karena mereka masih kurang memiliki pemahaman atau wawasan 
tentang diri dan lingkungan serta pengalaman untuk menentukan arah dikehidupan remaja (Corey, 2010). Dengan adanya proes bimbingan juga dapat membantu remaja dalam membentuk sikap yang lebih baik dan terarah sehingga dapat terhindar dari hal-hal yang negatif.

Disini Bimbingan Konseling Islam merupakan pembinaan bagi remaja sebagai bagian dalam proses sosialisasi yang penting dan mendasar karena fungsi utama pembinaan remaja sangatlah penting dalam membentuk karakter, dan menambah pengetahuan tentang agama Islam bagi remaja. Pembinaan moral dan pemahaman agama Islam terhadap remaja seharusnya ditanamkan sejak kecil, sesuai dengan masing-masing kemampuan dan umurnya. Setiap generasi muda yang lahir belum mengerti mana yang benar, mana yang salah, belum mengerti tentang batas-batas ketentuan moral yang berlaku dalam lingkungannya dan perintah atau larangan-larangan dalam ajaran Islam.

Dalam Islam, kewajiban ditempatkan sebagai salah satu hukum syara', yaitu merupakan suatu perbutan yang apabila dikerjakan akan mendapatkan pahala sedangkan jika ditinggalkan akan disiksa. Bahwa kewajiban dalam agama berkaitan dengan pelaksanaan hak kewajiban dalam agama, berkaitan dengan pelaksanaan hak yang diwajibkan oleh Allah, seperti melaksanakan sholat lima waktu, membayar zakat bagi yang memiliki harta tertentu dan sampai batas nisab dan berpuasa di bulan Ramadhan adalah merupakan suatu kewajiban (Hawa, 2018).

Salah satu kewajiban dalam agama ialah ibadah shalat. Ibadah shalat merupakan kewajiban yang paling penting dari pada ibadah lainnya. Shalat merupakan ibadah yang paling penting, antara lain karena tegak tidaknya Islam seseorang itu terletak pada pelaksaan ibadah shalatnya, baik buruknya amal perbuatan seseorang itu terletak pada baik buruknya shalat, dengan mendirikan shalat akan selalu mendapat rahmat Allah SWT, serta shalat merupakan pembuka kunci surga.

Pentingnya shalat itu pada dasarnya merupakan untuk manusia sendiri. Oleh karena itulah maka Allah SWT mewajibkan semua manusia yang diciptakan-Nya untuk beribadah shalat kepada-Nya. Firman Allah sebagai berikut:

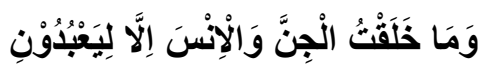
Artinya: Dan aku tidak menciptakan jin dan manusia melainkan supaya mereka mengabdi kepada-Ku (Q.S Adh Dzariyat :56).

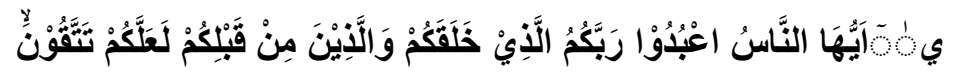


Artinya : Hai manusia, sembahlah Tuhanmu yang telah menciptakanmu dan orang-orang yang sebelummu, agar kamu bertaqwa (Q.S Al-Baqarah : 21) (Rubino, 2018).

Dampak shalat bagi seseorang yang melaksanakannya akan menumbuhkan sifat keruhanian dalam diri manusia yang menjadikannya tercegah dari perbuatan-perbuatan keji dan mungkar (Ulya, 2011). Seperti firman Allah yang dijelaskan dari Q.S Al Ankabut : 45 sebagai berikut :

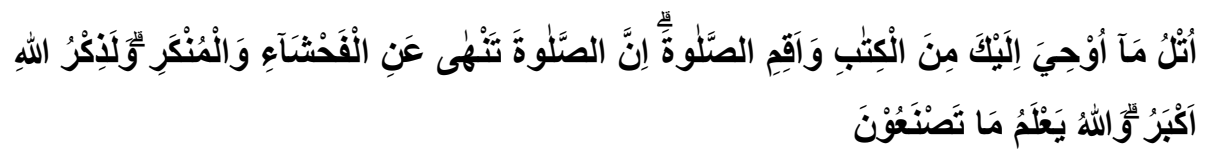

Artinya : Bacalah kitab (Al-Qur'an) yang telah diwahyukan kepadamu (Muhammad) dan laksanakanlah shalat. Sesungguhnya shalat itu mencegah dari (perbuatan) keji dan munkar. Dan (ketahuilah) mengingat Allah (shalat) itu lebih besar keutamaannya dari ibadah lain. Allah mengetahui apa yang kamu kerjakan (Q.S Al-Ankabut : 45).

Kurangnya pemahaman agama menjadi salah satu faktor munculnya perilaku yang menyimpang terhadap remaja, perilaku tersebut bisa terjadi ketika individu tidak memiliki dasar agama yang kuat sehingga mudah dipengaruhi oleh kondisi dilingkungan sekitarnya, dengan ini perlu adanya proses pendampingan belajar dan pendidikan keagamaan. Dengan harapan agar remaja dapat terhindar dari perilaku menyimpang yang biasanya muncul dari pengaruh lingkungannya. Arah yang ditempuh ini adalah bertujuan untuk pengembangan fitrah dan kembali kepada fitrah (Sutoyo, 2013).

Peran bimbingan sangat penting dalam proses pembentukan karakter remaja yang paling utama adalah bimbingan terhadap sikap kesadaran beragama remaja. Dalam Islam bimbingan merupakan bagian dakwah Islamiah. Dakwah disini adalah kegiatan menyeru dan mengajak kepada manusia untuk melakukan kebaikan dan menjauhi kemungkaran. Kurangnya kesadaran sholat lima waktu menimbulkan banyaknya perilaku yang menyimpang yang dilakukan oleh remaja, maka dari itu perlu adanya bimbingan terutama dalam meningkatkan kesadaran sholat lima waktu. Remaja yang dibimbing mempunyai keimanan yang benar dan secara perlahan mampu meningkatkan kualitas kepatuhan terhadap Allah SWT, dalam bentuk kepatuhan terhadap suatu hukum dan ketaatan dalam beribadah sesuai aturanNya (Saifullah, 2017).

Bimbingan Konseling Islam merupakan suatu usaha yang dapat dilakukan dalam rangka mengembangkan potensi dan memecahkan suatu permasalahan yang dialami klien agar dapat mencapai kebahagiaan hidup di dunia dan kebahagiaan hidup di akhirat 
berdasarkan ajaran Islam. Bimbingan dan konseling Islam memiliki fungsi sebagai pencegahan dan pemeliharaan agar dapat meningkatkan Iman, Islam, Ikhsan agar remaja tidak terjerumus kedalam hal-hal yang negatif.

Terkait dengan permasalahan tersebut, terdapat fenomena dimana ada seorang remaja di Dusun Semare Desa Glawan Kecamatan Pabelan Kabupaten Semarang berusia 17 tahun. Dia sering meninggalkan kewajibannya untuk melaksanakan sholat lima waktu. Remaja tersebut seringkali dimanja oleh ibunya tentang apa yang dia inginkan ibunya berusaha selalu menurutinya. Remaja ini merupakan anak tunggal. Remaja ini kurang perhatian dari orang tuanya, ayah remaja merupakan ayah sambungnya dan tidak begitu dekat dengan remaja ini sedangkan ibunya sibuk bekerja dan pulang sampai malam terkadang. Remaja ini jarang sekali keluar dari kamarnya, ia selalu di kamarnya untuk main game dan nonton film, karena remaja ini merasa kesepian ketika di rumah. Remaja ini selalu menolak apa yang diperintahkan oleh ibunya dengan berbagai kebohongan untuk dijadikan alasan yang sebenarnya remaja ini tidak mau disuruh oleh ibunya.

Dalam penelitian ini penulis mengambil puasa senin kamis. Puasa senin kamis ialah ibadah yang sangat dianjurkan oleh Rasulullah SAW. Puasa senin kamis ini memiliki makna yang puasanya dilakukan pada hari senin, hari kamis dan Rasulullah SAW suka melaksanakan puasa tersebut, dengan alasan bahwa pada hari senin dan kamis semua amalan akan diangkat kehadapan Allah SWT dalam keadaan puasa. Penulis mengambil puasa pada hari senin dan kamis ini untuk meningkatkan kesadaran sholat lima waktu dan melihat perubahan konseli saat berpuasa dan saat tidak berpuasa, sehingga peneliti tahu dan melatih konseli untuk berpuasa untuk meningkatkan kesadaran sholat lima waktu.

Puasa senin dan kamis ini melatih untuk menghindarkan dari perbuatan dosa dan menjalankan kewajiban. Pada saat berpuasa, seseorang akan memerangi hal-hal yang buruk, sehingga setelah berpuasa akan lebih bisa menahan perbuatan yang membatalkan puasa seperti meninggalkan kewajiban beribadah kepada Allah SWT. Puasa senin dan kamis ini bisa meningkatkan amal kita serta kita bisa lebih dekat dengan Allah dan lebih bertaqwa. Kekuatan internal yang diperoleh saat berpuasa yang menjadi mekanisme control diri untuk melakukan apa yang seharusnya dilakukan atau ditinggalkan.

Terdapat beberapa hasil penelitian terdahulu yang relevan memberikan sebuah pemparan mengenai penelitian terdahulu yang dilakukan oleh peneliti sebelumnya. Pertama, penelitian yang berjudul "Pengaruh Bimbingan Konseling Agama Islam dalam 
Mengatasi Kenakalan Remaja di SMA Negeri 3 Kota Tangeran Selatan”. Penelitian tersebut menggunakan deskriptif analisis. Hasil dari penelitian tersebut adalah siswa kelas XI di SMA 3 Kota Tangeran Selatan memiliki tingkat kenakalan yang rekatif masih rendah, seperti menentang dan membantah orang tua atau guru, melanggar peraturan sekolah dan lain-lain. Adapun pelayanan yang dilakukan oleh guru agama islam untuk mengatasi kenakalan remaja di SMA 3 kota Tangeran Selatan dengan mengadakan bimbingan membaca AL-Qur'an, memberi perhatian khusus untuk siswa yang bermasalah, mengadakan praktek kegiatan keagamaan seperti sholat jenazah, istikhoroh dan membimbing siswa untuk mengikuti kegiatan positif. Persamaan dari penelitian ini adalah sama-sama menggunakan Bimbingan Konseling Islam untuk remaja. Sedangkan perbedaannya di focus permasalahan antara kenakalan remaja dan kesadaran sholat lima waktu.

Kedua, penelitian yang berjudul "Konsep Pembentukan Karakter Siddiq dan Amanah pada Anak Melalui Pembiasaan Puasa Sunnah”. Hasil penelitian tersebut dapat disimpulkan bahwa pembiasaan puasa sunnag kepada anak akan melatih anak dalam mengendalikan diri ke hal yang positif yang nantinya sangat berguna bagi kehidupan dewasanya. Selain itu anak sudah dilatih untuk lebih mendekatkan diri kepada Allah melalui dengan pembiasaan puasa sunnah. Persamaan dari penelitian ini ialah sama-sama menerapkan puasa sunnah, sedangkan perbedaannya ialah disasarannya antara anak dan remaja.

\section{METODE}

Penelitian ini menggunakan pendekatan kualitatif. Penelitian kualitatif adalah penelitian yang menggunakan latar alamiah dengan maksud menafsirkan fenomena yang terjadi dengan jalan melibatkan berbagai Teknik yang ada. Pendekatan kualitatif merupakan penelitian yang menghasilkan data deskriptif kata-kata tertulis atau lisan dari orang-orang dan pelaku yang dapat diamati. Jenis penelitian yang digunakan dalam penelitian ini adalah studi kasus. Studi kasus merupakan sebuah penelitian dimana peneliti mengamati dan berpartisipasi secara langsung dan mengenai social tertentu sehingga dapat memberikan gambaran secara luas dan mengenai unit sosial (Assegaf, 2019).

Pengumpulan data dilakukan melalui beberapa teknik pengumpulan data dalam penelitian kualitatif yang peneliti gunakan yaitu ada wawancara, wawancara adalah 
merupakan pertemuan dua orang untuk bertukar informasi dan ide melalui tanya jawab, sehingga dapat dikontruksikan makna dalam suatu topik tertentu (Sugiyono, 2006). Dari teknik wawancara ini peneliti dapat menggali data dari konseli tersebut, dan data yang digali merupakan data primer dari konseli langsung dan data sekunder dari orang lain. Data yang diambil saat wawancara merupakan data latar belakang, identitas, proses terapi dan hasil terapi. Jenis wawancara yang digunakan oleh penulis adalah Wawancara Tak Berstruktur, dimana pada proses wawancara ini penulis tidak menggunakan pedoman wawancara yang telah tersusun sebelumnya, pedoman wawancara yang digunakan penulis hanya berupa garis-garis besarnya dalam suatu permasalahan.

Selanjutnya ada observasi. observasi diartikan sebagai pengamatan dan pencatatan secara sistematik terhadap suatu gejala yang tampak pada objek penelitian. Observasi merupakan pengamatan terhadap peristiwa yang diamati secara langsung oleh penulis. Jadi observasi merupakan pengamatan dan penelitian yang sistematis terhadap suatu gejala yang diteliti (Sugiyono, 2015). Observasi disini penulis akan mencari informasi tentang kebiasaan konseli dalam keseharian.

Terakhir dokumentasi, dokumentasi merupakan catatan peristiwa yang sudah berlalu. Dokumen dapat berbentuk tulisan, gambar atau karya-karya monumental dari seseorang. Dokumen yang berbentuk tulisan misalnya catatan harian, sejarah kehidupan, biografi, peraturan dan kebijakan. Dokumen yang berbentuk gambar misanya foto, gambar hidup, sketsa dan lain sebagainya. Dokumen yang berbentuk karya misalnya karya seni yang dapat berupa gambar, patung, film, dan lain-lain (Sugiyono, 2006). Dokumentasi digunakan untuk mengumpulkan data tentang proses konseling.

Kemudian analisis yang digunakan dalam penelitian ini yaitu teknik analisis deskriptif. Untuk mengetahui bagaimana cara remaja tersebut (konseli) mampu melaksanakan sholat 5 waktu dan mendengarkan perkataan orang tuanya dengan menggunakan analisis deskriptif komparatif. Selanjutnya Analisa proses dan hasil pelaksanaan Bimbingan Konseling Islam dengan terapi puasa dalam meningkatkan kesadan shalat lima waktu dilakukan dengan analisis deskriptif komparatif, yaitu dengan membandingkan pelaksanaan Bimbingan Konseling Islam dengan teori pada umumnya, lalu membandingkan keadaan konseli sebelum dan sesudah dilakukan proses konseling. 


\section{HASIL DAN BAHASAN}

Dalam proses pelaksanaan Bimbingan Konseling Islam dengan Terapi Puasa dalam meningkatkan kesadaran Shalat Lima Waktu Remaja dilakukan dengan penyesuaian jadwal remaja (konseli) dan beberapa narasumber lainnya. Adapun langkah-langkah konselor selama proses konseling, pertama identifikasi masalah merupakan langkah awal dalam penelitian untuk menjalankan proses konseling. Langkah ini digunakan penulis (konselor) untuk menggali permasalahan remaja (konseli).

Kedua ada diagnosa, diagnosa merupakan penetapan suatu keadaan yang menyimpang atau keadaan normal melalui dasar pemikiran dan pertimbangan. Dari diagnosa tersebut masalah yang di tetapkan konselor ialah remaja yang kesadaran shalat lima waktunya kurang. Masalah tersebut disebabkan karena konseli merasa kesepian di rumah dan kurangnya perhatian dari orang tuanya. Konseli lebih memilih sering di kamarnya dan main hp dari pada kumpul dengan ibu, ayah dan neneknya.

Ketiga prognosa, prognosa adalah prediksi tentang kemungkinan yang akan terjadi dengan memperhatikan dari berbagai aspek. Konselor menetapkan bahwa perilaku meninggalkan sholat dan membantah orang tua di sebabkan karena kesadaran dalam pentingnya melaksanakan shalat yang kurang, suasana di rumah yang terasa sepi, dan kurangnya perhatian orang tua terhadap konseli. Dalam hal ini konselor menetapkan terapi puasa sunnah untuk meningkatkan kesadaran shalat lima waktu yang diberikan kepada remaja (konseli) tersebut.

Keempat treatmen atau terapi adalah proses pemberian bantuan dari konselor kepada konseli yang sedang mengalami masalah. Dalam hal ini konselor menggunakan Bimbingan Konseling Islam dengan terapi puasa sunnah sebagai treatmen yang diberikan kepada konseli. Alasan konselor memilih terapi puasa sunnah, karena puasa itu merupakan latihan bagi umat manusia untuk bersabar dalam menahan lapar, haus, dan mencegah hawa nafsu. Latihan mengendalikan diri dan mengatasi bahwa nafsu sebagai proses belajar untuk mempunyai kehendak yang kuat, kemauan yang teguh, tidak hanya mengendalikan hawa nafsu saja, tetapi juga tingkah laku yang terutama pada kehidupan dalam melaksanakan kewajiban sebagai umat muslim. Dalam pemberian treatmen ini konselor menyuruh konseli untuk melaksanakan puasa mulai pada tanggal 22 Maret 2021. Pada tahap ini konselor memberi nasehat kepada konseli untuk berpuasa sunnah di hari senin dan kamis. Langkah selanjutnya konselor menyuruh konseli untuk mengisi angket 
perilaku shalat lima waktu, konselor meminta konseli untuk memberi centang dipilihan "Ya" dan "Tidak" beserta alasan mengapa tidak melaksanakan shalat selama satu minggu, kemudian konselor melihat catatan saat berpuasa dan tidak berpuasa. Konselor akan mengecek perkembangan konseli selama satu minggu sekali, guna melihat perbedaan perilaku sebelumnya. Konselor memantau perubahan diri konseli dengan melihat hasil catatan yang dibuat konseli dan melakukan wawancara kepada nenek dan ibu konseli mengenai angket yang konseli isi, untuk mengetahui apakah benar adanya. Langkah terakhir dalam treatmen ini konseli memberikan suatu pemahaman mengenai pentingnya melaksanakan shalat lima waktu.

Kelima ada evaluasi dan follow up, dalam tahap ini konselor dapat mengetahui sejauh mana keberhasilan bantuan yang telah diberikan dalam proses konsling dengan Bimbingan Konseling Islam dengan Terapi Puasa sebagai treatment atau terapi.

Penelitian yang dilakukan pada konseli ini bertujuan untuk meningkatkan kesadaran shalat lima waktu dengan menggunakan terapi puasa senin kamis. Hasil penelitian ini bahwa konseli dikit demi sedikit menampakan perubahan yang positif, konseli mulai sadar bahwa shalat itu penting bagi dirinya. Pernyataan tersebut terbukti dari hasil wawancara data sekunder yaitu nenek konseli. Perubahan yang jelas terlihat dalam diri konseli yaitu konseli tidak lagi meninggalkan shalat, konseli mulai mendengarkan perintah ibunya, dan mulai mengurangi bermain HP. Ibu konseli juga mulai memberikan perhatian kepada konseli seperti menanyakan tugas sekolahnya, menyuruh konseli untuk makan, mengingatkan konseli untuk shalat, dan terkadang mengajak konseli untuk shalat berjamaah.

Tabel 1

Hasil Catatan Harian Perilaku Konseli Pada tanggal 22-28 Maret 2021

\begin{tabular}{|c|c|c|}
\hline Hari/Tanggal & Perilaku & Hasil Wawancara \\
\hline Senin, 22 Maret 2021 & $\begin{array}{l}\text { Konseli meninggalkan shalat subuh dan } \\
\text { beralasan saat ibunya meminta bantuan }\end{array}$ & \multirow{7}{*}{$\begin{array}{c}\text { Wawancara kepada Ibu dan } \\
\text { nenek konseli }\end{array}$} \\
\hline Selasa, 23 Maret 2021 & Konseli melaksanakan shalat 5 waktu & \\
\hline Rabu, 24 Maret 2021 & $\begin{array}{l}\text { Konseli meninggalkan shalat subuh dan } \\
\text { ashar }\end{array}$ & \\
\hline Kamis, 25 Maret 2021 & $\begin{array}{l}\text { konseli melaksanakan shalat } 5 \text { waktu, } \\
\text { konseli tidak membantu ibunya }\end{array}$ & \\
\hline Jum'at, 26 Maret 2021 & Konseli meninggalkan shalat ashar dan isya' & \\
\hline Sabtu, 27 Maret 2021 & Konseli melaksanakan shalat 5 waktu & \\
\hline Minggu, 28 Maret 2021 & $\begin{array}{l}\text { Konseli melaksanakan shalat } 5 \text { waktu dan } \\
\text { mulai membantu ibunya }\end{array}$ & \\
\hline
\end{tabular}




\section{Tabel 2}

Hasil Catatan Harian Perilaku Konseli

Pada tanggal 29 Maret-4 April 2021

\begin{tabular}{ccc}
\hline Hari/Tanggal & Perilaku & Hasil Wawancara \\
\hline Senin, 29 Maret 2021 & $\begin{array}{c}\text { Konseli melaksanakan shalat 5 } \\
\text { waktu }\end{array}$ & \\
\cline { 1 - 2 } Selasa, 30 Maret 2021 & $\begin{array}{c}\text { Konseli meninggalkan shalat } \\
\text { subuh }\end{array}$ & \\
\hline Rabu, 31 Maret 2021 & $\begin{array}{c}\text { Konseli melaksanakan shalat 5 } \\
\text { waktu dan membantu ibunya }\end{array}$ & \\
\hline Kamis, 1 April 2021 & $\begin{array}{c}\text { konseli melaksanakan shalat 5 } \\
\text { waktu }\end{array}$ & $\begin{array}{c}\text { Wancara kepada Ibu dan } \\
\text { nenek konseli }\end{array}$ \\
\hline Jum'at, 2 April 2021 & $\begin{array}{c}\text { Konseli melaksankan sholat 5 } \\
\text { waktu }\end{array}$ & \\
\hline Sabtu, 3 April 2021 & $\begin{array}{c}\text { Konseli meninggalkan shalat } \\
\text { isya }\end{array}$ \\
\hline Minggu, 4 April 2021 & $\begin{array}{c}\text { Konseli melaksanakan shalat 5 } \\
\text { waktu dan membantu ibunya }\end{array}$ & \\
\hline &
\end{tabular}

Tabel 3

Hasil Catatan Harian Perilaku Konseli

Pada tanggal 5-11 April 2021

\begin{tabular}{|c|c|c|}
\hline Hari/Tanggal & Perilaku & Hasil Wawancara \\
\hline Senin, 5 April 2021 & $\begin{array}{c}\text { Konseli melaksanakan shalat } 5 \\
\text { waktu }\end{array}$ & \multirow{7}{*}{$\begin{array}{c}\text { Wawancara kepada Ibu dan } \\
\text { nenek konseli }\end{array}$} \\
\hline Selasa, 6 April 2021 & $\begin{array}{c}\text { Konseli melaksanakn shalat } 5 \\
\text { waktu }\end{array}$ & \\
\hline Rabu, 7 April 2021 & $\begin{array}{c}\text { Konseli melaksanakan shalat } 5 \\
\text { waktu dan membantu ibunya }\end{array}$ & \\
\hline Kamis, 8 April 2021 & $\begin{array}{l}\text { konseli melaksanakan shalat } 5 \\
\text { waktu }\end{array}$ & \\
\hline Jum'at, 9 April 2021 & $\begin{array}{c}\text { Konseli melaksankan sholat } 5 \\
\text { waktu }\end{array}$ & \\
\hline Sabtu, 10 April 2021 & $\begin{array}{l}\text { Konseli melaksanakan shalat } 5 \\
\text { waktu }\end{array}$ & \\
\hline Minggu, 11 April 2021 & $\begin{array}{l}\text { Konseli melaksanakan shalat } 5 \\
\text { waktu dan membantu ibunya }\end{array}$ & \\
\hline
\end{tabular}

Berdasarkan hasil diatas perilaku konseli dari minggu ke minggu mengalami perubahan setelah dilaksanakan proses konseling, namun perubahan itu tidak langsung berubah total melainkan dengan cara bertahap. Konseli diberi arahan terus sampai konseli dapat melaksankan shalat 5 waktu. Kemudian di dalam penelitian ini juga telah membuktikan bahwa penyesuaian diri tidak dapat dilihat hanya dengan faktor perbedaan latar belakang sekolah, karena mahasantri yang berasal dari pondok pesantren dan sekolah umum dalam penyesuaian dirinya kepada lingkungan baru terkhusus di Ma'had AlJami'ah memiliki tingkat penyesuaian diri yang tidak jauh berbeda atau tidak memiliki perbedaan yang signifikan. 


\section{Tabel 4}

Perbedaan Perilaku Konseli Sebelum dan Sesudah

\begin{tabular}{|c|c|c|c|c|c|}
\hline No. & Perilaku Konseli Sebelum Konseling & $\mathbf{A}$ & B & $\mathbf{C}$ & $\mathbf{D}$ \\
\hline \multirow[t]{2}{*}{1.} & Melaksanakan Shalat 5 waktu & & $\sqrt{ }$ & & \\
\hline & Membantu Ibunya & $\sqrt{ }$ & & & \\
\hline \multirow[t]{3}{*}{2.} & Perilaku Konseli Sesudah Konseling & $\mathbf{A}$ & $\mathbf{B}$ & $\mathbf{C}$ & $\mathbf{D}$ \\
\hline & Melaksanakan Shalat 5 waktu & & & & $\sqrt{ }$ \\
\hline & Membantu Ibunya & & & $\sqrt{ }$ & \\
\hline
\end{tabular}

Keterangan A: Tidak Pernah, B: Kadang-Kadang, C: Dilakukan, D: Selalu dilakukan

Berdasarkan tabel di atas menunjukan perilaku konseli. Konseli yang kadangkadang bahkan tidak pernah dilakukan oleh diri konseli sebelum dilakukan proses konseling. Perilaku tersebut sedikit demi sedikit dapat berkurang seiring dengan dilaksanakannya proses konseling dan pemberian treatment pada konseli.

\section{KESIMPULAN}

Hasil dari proses pelaksanaan Layanan Bimbingan Konseling Islam dengan terapi puasa senin kamis dalam meningkatkan kesadaran shalat lima waktu remaja, kesimpulannya layanan Bimbingan Konseling Islam dengan terapi puasa senin kamis dalam meningkatkan kesadaran shalat lima waktu remaja sudah melalui 5 proses yakni identifikasi masalah, diagnosis, prognosis, treatment/terapi, dan yang terakhir ada evaluasi dan follow up. Disini konselor memberikan pengertian puasa senin dan kamis seperti yang dicontohkan Rasululullah yang melaksanakan puasa senin dan kamis, supaya Ketika amal perbuatan Rasulullah dilaporkan, Rasulullah dalam keadaan puasa sehingga dapat menghapus dosa-dosanya. Konselor menyuruh konseli berpuasa senin dan kamis sebagai treatmen agar konseli sadar akan pentingnya shalat, tidak hanya itu konseli juga disuruh mengisi angket tentang perilaku shalat setiap harinya. Konseli juga diberi pemahaman akan pentingnya shalat. Serta ibu konseli juga diberikan motivasi dan nasehat agar lebih memperhatikan putrinya dan mencontohkan perilaku baik agar putrinya juga meniru perilaku baik tersebut. Hasil akhir dalam pemberian terapi puasa dalam meningkatkan kesadaran shalat 5 waktu, adanya perubahan dalam diri konseli, sedikit demi sedikit konseli tidak lagi meninggalkan shalat 5 waktu dan mulai menuruti dan membantu ibunya. Perubahan tersebut merupakan perubahan yang diinginkan oleh orang tua dan nenek konseli. Disini ibu konseli juga menampakan sebuah perubahan yang positif karena dampak positif akan berguna bagi orang-orang disekitar konseli. 
Rekomendasi penelitian ini diperuntukan bagi: (1) Konselor, konselor harus lebih sering dalam melakukan praktek konseling, entah itu dengan temannya sendiri supaya konselor lebih terbiasa melakukan konseling, bisa lebih professional saat proses konseling. Konselor harus lebih banyak lagi membaca jurnal-jurnal, buku sebelum memberikan treatment. Konselor lebih meningkatkan skill dan komunikasi dengan konseli agar proses konseling berjalan dengan lancer dan konseli merasa nyaman. (2) Konseli, kita hidup tidak hanya untuk dunia saja, mulailah mengejar akhiratmu, perbanyak dalam mendekatkan diri kepada Allah agar dapat membawa orang tua masuk surga. yang dapat membentuk diri kita ya akita sendiri, mulailah membahagiakan orang tua selagi orang tuamu masih ada.

\section{DAFTAR RUJUKAN}

Assegaf, S. (2019). Bimbingan Keagamaan dalam Pembinaan Moral Remaja pada Majlis Taklim Riyadhul Musthofa Kampung Sawah Bandar Lampung. (Unpublished master's thesis) Universitas Islam Negeri (UIN) Raden Intan, Lampung, Indonesia.

Corey, G. (2010). Teori dan Praktik Konseling dan Psikoterapi. Terjemahan E. Koswara. Bandung: Refika Aditama

Hawa, S. (2018). Metode Bimbingan Islam dalam Pembinaan Kesadaran Beragama Lansia. (Unpublished master's thesis) Universitas Islam Negeri Ar-Raniry, Banda Aceh, Indonesia.

Hidayati, K.B. \& Farid, M. (2016). Konsep Diri, Adversity Quotient dan Penyesuaian Diri pada Remaja. Persona: Jurnal Psikologi Indonesia, 5(2), 137 144. https://doi.org/10.30996/persona.v5i02.730

Jannah, M., Yacob, F., Julianto, (2017). Rentang Kehidupan Manusia (Life Span Development) dalam Islam. International Journal of Child and Gender Studies, 3(1), 97-114. http://dx.doi.org/10.22373/equality.v3i1.1952

Padli, R, (2018). Peran Bimbingan Orang tua dalam Meningkatkan Kesadadan Beragama Remaja di Desa Tulak Tallu Kecamatan Sabbang Kabupaten Luwu Utara. (Unpublished master's thesis) IAIN Palopo, Sulawesi, Indonesia

Rubino. (2018). Studi Korelasi tentang Pemahaman Pentingnya Ibadah Shalat dan Pengamalannya. Jurnal Pendidikan Madrasah, 3(1), 199-206

Saifullah. (2017). Konsep Pembentukan Siddiq dan Amanah pada Anak melalui Pembiasaan Puasa Sunnah. Jurnal Mudarrisuna, 7(1), 11-102.

Sugiyono. (2006). Metode Penelitian Pendidikan Pendekatan Kuantitatif Kualitatif dan $R \& D$. Bandung: Alfabeta.

Sugiyono. (2015). Metode Penelitian Kuantitatif. Kualitatif dan R\&D. Bandung: Alfabeta.

Sutoyo, A. (2013). Bimbingan dan Konseling Islami (teori dan praktek). Yogyakarta: Pustaka Pelajar.

Ulya, F. (2011). Implikasi Shalat dalam Membentuk Kepribadian Perempuan. Jurnal Musawa. 10(1), 135-156. https://doi.org/10.14421/musawa.2011.101.135-156 